\title{
Biodegradation of the Organophosphorus Insecticide Diazinon by Pseudomonas aeruginosa Isolated from Agricultural Drainage Ditches
}

\author{
A.M.M. Essa ${ }^{1 *}$, Amany M. Reyad ${ }^{1}$, T.E.E. $\operatorname{Radwan}^{1}$ and \\ W.M. Ibrahim ${ }^{2}$ \\ ${ }^{1}$ Botany Department, Faculty of Science, Fayoum University \\ and ${ }^{2}$ Botany Department, Faculty of Science, Damanhour \\ University, Egypt
}

\begin{abstract}
D IAZINON is an organophosphorous insecticide that is commonly used to control various agricultural and household pests and is frequently found as contaminant in water bodies. In the present study, a diazinon degrading bacterium was isolated from agricultural drainage ditches (Fayoum, Egypt) by enrichment technique. Based on morphological, biochemical and 16S rDNA gene sequencing, it was identified as Pseudomonas aeruginosa. A pure culture of $P$. aeruginosa was grown in minimal medium supplemented with diazinon as sole carbon source. The influence of diazinon concentration, temperature and $\mathrm{pH}$ on the bacterial growth and rate of diazinon degradation was investigated. The maximum capability of diazinon degradation $(83.6 \%)$ was achieved at concentration $400 \mathrm{ppm}$ of diazinon at $\mathrm{pH}$ value 7.0 and temperature $30^{\circ} \mathrm{C}$ within 14 days. Therefore, $P$. aeruginosa can be used efficiently for the environmental cleanup of agricultural wastewater contaminated with high levels of diazinon.
\end{abstract}

Keywords: Pseudomonas aeruginosa, Diazinon, Biodegradation, 16S rDNA.

Pesticides that are used for crop protection are considered to be most widely distributed contaminants in the environment. Huge amounts of pesticides are produced and spread annually worldwide (Courdouan et al., 2004). The excessive use of pesticides has resulted in problems caused by their interaction with biological systems in the ecosystem (Kanekar et al., 2004). The quality of soils, ground water, surface water and air is negatively affected by pesticide contamination (Surekha et al., 2008). As a result of the accumulation of pesticides in water supplies, there is an increasing necessity to develop environmentally safe, convenient and cost-effective techniques for the removal of pesticides (Zhang and Quiao, 2002 and Hussaini et al., 2013).

Currently, the pesticides cleaning up methods such as chemical treatment, volatilization and incineration have several handicaps such as the production of large quantities of chemicals and emission of toxic compounds (Liu et al., 2003).

*Corresponding author: Ashraf M. M. Essa - E-mail: ashraf.essa@ yahoo.com 
As a result of that the biological techniques such as bioremediation via utilizing microorganisms have been developed (Levin and Forchiassin, 2003 and Schoefs et al., 2004). Microorganisms have a chief impact on the persistence of most pesticides in soil (Surekha et al., 2008). Isolation of indigenous bacteria capable of metabolizing organophosphate pesticide compounds has received considerable attention in situ detoxification (Richins et al., 1997 and Mulchandani et al., 1999). Microorganisms can utilize organophosphorus pesticides as carbon and/or phosphorus sources after their degradation via specific pathways (Aislabie and Lloyd-Jones, 1995; Ibrahim and Essa, 2010).

Diazinon (O,O-diethyl O-2-isopropyl-6-methylpyrimidin-4-yl phosphorothioate) is organophosphorous insecticide (Fig. 1). It is commonly used to control agricultural and household pests (Tomlin, 2006). The toxicity of diazinon is attributed to the inhibition of acetylcholinesterase, a vital enzyme involved in neurotransmission, in the form of acetylcholine substitutes (Bakry et al., 2006).

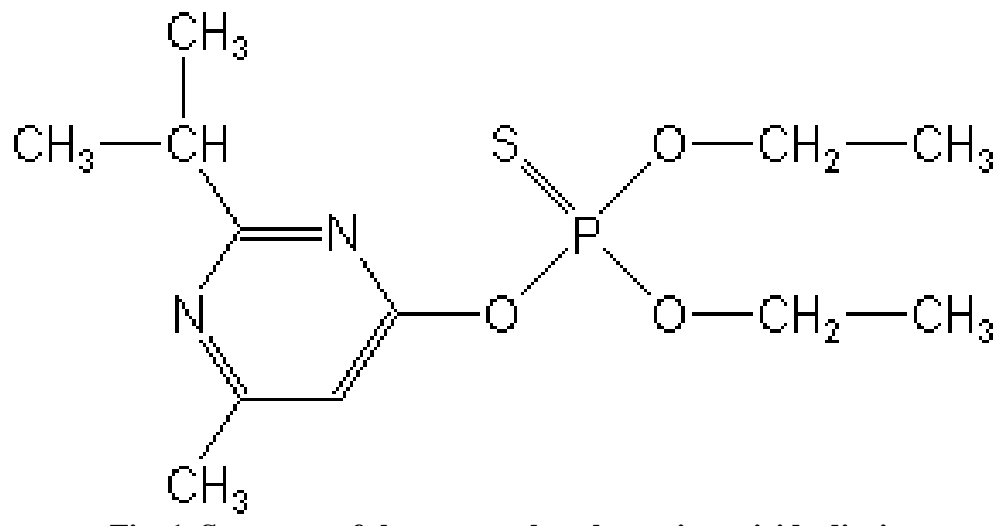

Fig. 1. Structure of the organophosphorus insecticide diazinon.

Diazinon can be hazardous as a result of runoff from areas of application into nearby drains or ditches, which typically transport water to streams and lakes. Subsequently it is subjected into degradation via biotic and abiotic processes (Getzin, 1967). Diazinon has a relatively short half-life in water, ranging from $70 \mathrm{hr}$ to 12 weeks depending on $\mathrm{pH}$, temperature, and sunlight as well as the presence of microorganisms while in soil it is influenced by the $\mathrm{pH}$ conditions in the soil and the soil type (Sethunathan and Yoshida, 1973).

Previous studies have showed that several bacterial species can utilize diazinon as a source of carbon and/or phosphorus such as Serratia marcescens (Abo-Amer and Aly 2011); Pseudomonas sp. (Ramanathan and Lalithakumari, 1999), Agrobacterium sp. (Yasouri, 2006); Arthrobacter sp. (Ohshiro et al., 1996) and Flavobacterium sp. (Ghassempour et al., 2002). Moreover, the some of these bacterial species might be contributed in the biotransformation of other organophosphorus insecticides (Lakshmi et al., 2008; Ortiz-Hernandez and Sanchez-Salinas, 2010).

Egypt. J. Bot., Vol. 56, No. 1 (2016) 
Diazinon is one of the common water pollutants in Egypt (Masoud et al., 2007). Thus the objectives of the present study were (i) to isolate diazinon tolerant bacteria from agricultural wastewater, (ii) to investigate the optimum conditions of diazinon biodegradation.

\section{Material and methods}

\section{Chemicals}

Diazinon was purchased from Riedel-de Haën, Sigma-Aldrich, Seelze, Germany. All other chemicals purchased are of analytical grade from Fluka AG, Buchs, Switzerland.

\section{Growth Media and Culture conditions}

The Mineral salt medium (MSM) used in isolation of bacteria from soil and diazinon degradation studies was consisting of $\left(\mathrm{NH}_{4}\right)_{2} \mathrm{SO}_{4}(2.0 \mathrm{~g} / \mathrm{L}) ; \mathrm{KH}_{2} \mathrm{PO}_{4}$ $(1.5 \mathrm{~g} / \mathrm{L}) ; \mathrm{Na}_{2} \mathrm{HPO}_{4}(1.5 \mathrm{~g} / \mathrm{L}) ; \mathrm{MgSO}_{4} .7 \mathrm{H}_{2} \mathrm{O},(0.2 \mathrm{~g} / \mathrm{L}) ; \mathrm{CaCl}_{2} .2 \mathrm{H}_{2} \mathrm{O}(0.01 \mathrm{~g} / \mathrm{L})$; $\mathrm{FeSO}_{4} .7 \mathrm{H}_{2} \mathrm{O}(0.001 \mathrm{~g} / \mathrm{L})$. The $\mathrm{pH}$ of the medium was adjusted to $7.0 \pm 0.1$ with 2 $\mathrm{M} \mathrm{NaOH}$. Diazinon was added to the liquid MSM medium after sterilization. For solid medium, $2 \%(\mathrm{w} / \mathrm{v})$ agar was added to the same diazinon containing liquid mineral salt medium. Stock solution of diazinon was prepared with a concentration $500 \mathrm{ppm}$ in acetone and was diluted to the required concentrations for the degradation studies.

\section{Isolation of diazinon degrading bacteria}

This experiment was performed to exclude sensitive bacteria and selecting the most tolerant bacteria to be acclimatized to diazinon. Five hundred milliliter of the agriculture wastewater was collected from El-Batts drain, Fayoum, Egypt. The samples were centrifuged under $10,000 \mathrm{rpm}$ for $10 \mathrm{~min}$ and reconstructed with $10 \mathrm{~mL}$ Milli-Q water. Forty five milliliter of liquid MSM medium supplemented with diazinon (100 ppm) was inoculated with $5 \mathrm{~mL}$ of bacterial suspension and incubated for $48 \mathrm{hr}$ inside shaking incubator $(120 \mathrm{rpm})$ at $30^{\circ} \mathrm{C}$. Aliquots were sub-cultured every 3 days for a total of five passes. The final culture was diluted and plated on diazinon agar plates. Developed colonies were repeatedly streaked on diazinon agar plates for isolation of pure cultures. The bacterial isolate designated AAD was chosen for this work because it was the most tolerant strain and can grow under elevated levels of diazinon up to $500 \mathrm{ppm}$. A pure culture of AAD isolate was then stored in solid MSM containing $100 \mathrm{ppm}$ diazinon for further studies.

\section{Morphological and biochemical tests}

The AAD isolate was tested for morphology, motility and Gram stain by phase contrast microscopy. Biochemical identification of the AAD isolate was performed according to Selim et al. (2014) using commercially available miniaturized multitest identification systems API (BioMérieux, France). Prior to inoculation of each identification system, a 24hr NA culture of AAD isolate was re-inoculated onto Nutrient agar plates to obtain isolated colonies for testing 
purposes. The API 20NE identification system is designed for identifying nonfastidious, non-enteric Gram-negative rods. Test strips were inoculated and incubated according to the instructions provided. Sterile $0.85 \%$ saline solution was used as a negative control. APIWEB software was used for identification and was considered acceptable when given a probability of $85 \%$ or greater.

\section{S rDNA identification}

The AAD diazinon degrading bacterial isolate was identified using $16 \mathrm{~S}$ rDNA gene sequencing technique. The genomic DNA was extracted according to Essa (2012). The primers used in the amplification of the 16S rDNA gene are forward primer (F1; AGA GTT TGA TCC TGG CTC AG) and reverse primer (R1; GGT TAC CTT GTT ACG ACT T). The PCR mixture was prepared as described by Reyad et al. (2014). PCR were carried out for 35 cycles under the following conditions: denaturation step at $94^{\circ} \mathrm{C}$ for $40 \mathrm{sec}$, annealing step at $55^{\circ} \mathrm{C}$ for $1 \mathrm{~min}$., extension step at $72^{\circ} \mathrm{C}$ for $2 \mathrm{~min}$. and final extension at $72^{\circ} \mathrm{C}$ for $10 \mathrm{~min}$. An aliquot of the PCR products $(10 \mu \mathrm{L})$ was mixed with $2 \mu \mathrm{L}$ of DNA loading buffer and analyzed by electrophoresis $(15 \mathrm{~V} / \mathrm{cm}, 60 \mathrm{~min}$.) on $0.7 \%$ horizontal agarose gel in TBE buffer containing $0.5 \mu \mathrm{g} / \mathrm{mL}$ ethidium bromide, then visualized on an UV transilluminator. Sequencing of the amplified fragments was performed at GATC Biotech, Constance, Germany. DNA Sequences were aligned at NCBI DataBase (www.ncbi.nlm.nlh.gov). Phylogenetic tree was then constructed by neighbour-joining method using TREEVIEW software (1.6.6) based on 16S rRNA gene sequences of some strains phylogenetically close to the isolated strain.

\section{Optimization of the growth conditions and diazinon biodegradation}

Experiments aiming to study the effect of diazinon concentration on the growth of the bacterial strain were conducted in $250 \mathrm{~mL}$ flask containing $50 \mathrm{~mL}$ MSM supplemented with different concentrations of diazinon (100-500 ppm). The medium was inoculated by five milliliter of bacterial cell suspension $\left(\mathrm{OD}_{600}\right.$ $=0.2)$ and incubated on a rotary shaker $(120 \mathrm{rpm})$ at $30^{\circ} \mathrm{C}$. Cell growth in liquid media was determined spectrophotometrically by measuring the cultural optical density at $600 \mathrm{~nm}$ at $24 \mathrm{hr}$ intervals over 21 days. The protein content of the bacterial cultures was assayed using Bradford assay (Bradford, 1976) in order to confirm the bacterial growth. To investigate the effect of $\mathrm{pH}$ value on the bacterial growth, experiments were carried out at different $\mathrm{pH}$ values. Cultures supplemented with $400 \mathrm{ppm}$ diazinon as a sole carbon source were incubated as mentioned above. At the same time, the effect of temperature on the bacterial growth was studied using MSM medium supplemented with $400 \mathrm{ppm}$ diazinon at the optimum $\mathrm{pH}$. Bacterial cultures were incubated at different temperatures. All the experiments were done in triplicates. Cell growth in liquid media was determined spectrophotometrically as mentioned above. The MSM supplemented with the same concentration of diazinon without bacterial inoculums were prepared and incubated under the same conditions in order to measure abiotic degradation of diazinon. 


\section{Analysis of the residual diazinon}

The capability of $P$. aeruginosa for diazinon biodegradation was determined under different temperatures and $\mathrm{pH}$ values after 14 days incubation in order to identify the optimum condition for diazinon degradation. The residual diazinon was extracted according to the method of Mahiudddin et al. (2014). About $50 \mathrm{~mL}$ of $90 \%$ methanol was added to $20 \mathrm{~mL}$ liquid culture and was set overnight. Then the mixture was filtrated and extracted twice with $50 \mathrm{~mL} \mathrm{CH}_{3} \mathrm{Cl}$. The received solution was concentrated under nitrogen flow to $1 \mathrm{~mL}$ to be determined by gas chromatography. A Hewlett-packard, USA serial 6890 gas chromatograph equipped with electron detector (ECD, Radioisotope Nuclide 63Ni) and HP PAS-1701 column $25 \mathrm{~m}$ length x $0.32 \mathrm{~mm}$ x 0.52 thickness. Pure nitrogen was used as carrier gas $(2 \mathrm{~mL} / \mathrm{min})$. Detector, injector and column temperature was 250, 240 and $225^{\circ} \mathrm{C}$, respectively. diazinon detection limit was set at concentration where the analyte signal was three times higher than background noise and it was $0.1 \mu \mathrm{g} / \mathrm{L}$. The diazinon degradation rate was calculated according to Lin et al. (2008) by the following formula:

$$
A=\left[C_{a}-C_{b} / C_{a}\right] \times 100
$$

where, (A) is the percentage of diazinon degradation, $\left(\mathrm{C}_{\mathrm{a}}\right)$ is the concentration of diazinon $(\mathrm{mg} / \mathrm{L})$ in the medium in absence of diazinon degrading strain, $\left(\mathrm{C}_{\mathrm{b}}\right)$ is the concentration of diazinon $(\mathrm{mg} / \mathrm{L})$ in presence of diazinon degrading strain.

\section{Statistics}

The data presented here are the mean values of three replicates. Standard errors were calculated for all the values using MS Excel 2007.

\section{Results}

\section{Isolation and identification of diazinon degrading bacteria}

Some bacterial species capable of degrading diazinon were isolated from agricultural drainage ditches in May, 2013 (Fayoum, Egypt) using enrichment technique. The bacterial isolate AAD was the most tolerant strain against high levels of diazinon $(500 \mathrm{ppm})$. A variety of morphological and biochemical assays were carried out to have a comprehensive view of the phenotypic characteristics of the bacterial isolate AAD as shown in Table 1. AAD isolate was Gram negative motile non-spore forming rods. This isolate demonstrated positive results with $\beta$-galactosidase, arginine dihydrolase, lysine decarboxylase, orenthine decarboxylase, urease, lipase, amylase, gelatinase, catalase, cytochrome oxidase, nitrate reduction and acetoin production tests. Meanwhile, negative results were recorded for tryptophane deaminase, $\mathrm{H}_{2} \mathrm{~S}$ production, indole production tests. Simultaneously, the AAD isolate showed the capability to utilize glucose, sucrose, mannitol, amygdalin, inositol, starch and citrate as carbon source. 
TABLE 1. Morphological and biochemical characters of the diazinon degrading bacterial isolate (AAD).

\begin{tabular}{|c|c|c|c|}
\hline Morphological characters & Result & Sugar fermentation & Result \\
\hline Gram staining & Negative & Glucose & Positive \\
\hline Motility & Motile & Sucrose & Positive \\
\hline Cell shape & Rod & Mannitol & Positive \\
\hline Endospore formation & Negative & Inositole & Negative \\
\hline Enzyme profile & & Rhamnose & Negative \\
\hline$\beta$-galactosidase & Positive & Melibiose & Negative \\
\hline Arginine dihydrolase & Positive & Amygdalin & Positive \\
\hline Lysine decarboxylase & Positive & Arabinose & Negative \\
\hline Orenthine decarboxylase & Positive & Starch & Positive \\
\hline Urease & Positive & Citrate utilization & Positive \\
\hline Tryptophane deaminase & Negative & Sorbitol & Negative \\
\hline Gelatinase & Positive & Other tests & \\
\hline Catalase & Positive & $\mathrm{H}_{2} \mathrm{~S}$ production & Negative \\
\hline Amylase & Positive & Acetoin production & Positive \\
\hline Lipase & Positive & Indole production & Negative \\
\hline Cytochrome oxidase & Positive & & \\
\hline Nitrate reduction & Positive & & \\
\hline -To nitrite & Positive & & \\
\hline -To $\mathrm{N}_{2}$ & Negative & & \\
\hline
\end{tabular}

The AAD isolate was identified as Pseudomonas aeruginosa using 16S rDNA gene sequencing technique with maximum homology of $87 \%$ Pseudomonas aeruginosa PAO1 strain PAO1 (accession number: NR0748281; Fig. 2). The phylogenetic tree of the diazinon degrading bacterial strain AAD and related bacterial species based on the $16 \mathrm{~S}$ rDNA sequence was provided in Fig. 3. It can be clearly seen that the AAD diazinon degrading strain was included in the genus Pseudomonas and closely related to the species aeruginosa. 
BIODEGRADATION OF THE ORGANOPHOSPHORUS INSECTICIDE... 359

\begin{tabular}{|c|c|c|c|}
\hline AAD & 93 & 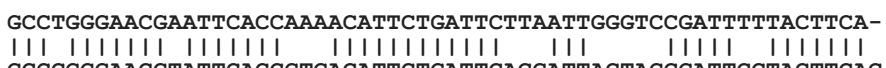 & 151 \\
\hline Sbjet & 310 & GCCCGGGAACGTATTCACCGTGACATTCTGATTCACGATTACTAGCGATTCCTACTTCAC & \\
\hline AAD & 52 & AATTCGAGTTGCAGACTGAAATCGGGAAGA-GATGGGTTTTGTGGAATTACTTCCACCT & 10 \\
\hline Sbjet & 1250 & 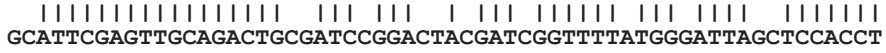 & 191 \\
\hline AAD & 211 & CGGTGCTTGGCAACCCTTTGT-CCGA-ATTTGTACAACGTGTGAAGCCCTGGCCGTAAGG & 268 \\
\hline Sbjet & 1190 & 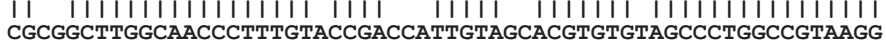 & \\
\hline AAD & 69 & 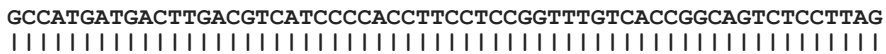 & 328 \\
\hline Sbjet & 130 & GCCATGATGACTTGACGTCATCCCCACCTTCCTCCGGTTTGTCACCGGCAGTCTCCTTAG & 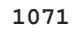 \\
\hline AAD & 329 & 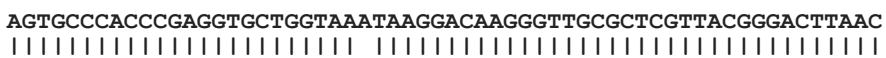 & 388 \\
\hline Sbjet & 1070 & AGTGCCCACCCGAGGTGCTGGTAACTAAGGACAAGGGTTGCGCTCGTTACGGGACTTAAC & 011 \\
\hline AAD & 389 & CCAACATCTCACGACACGAGCTGACGACCGCCATGCAGCACCTGTGTCTGAGTTCCCAAA & 48 \\
\hline Sbjet & 010 & CCAACATCTCACGACACGAGCTGACGACAGCCATGCAGCACCTGTGTCTGAGTTCCCGAA & 951 \\
\hline AAD & 449 & 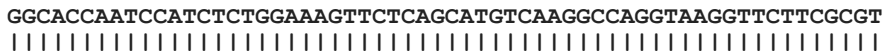 & 08 \\
\hline Sbjet & 950 & GGCACCAATCCATCTCTGGAAAGTTCTCAGCATGTCAAGGCCAGGTAAGGTTCTTCGCGT & 891 \\
\hline AAD & 509 & 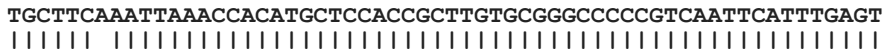 & 68 \\
\hline Sbjet & 90 & GCTTCGAATTAAACCACATGCTCCACCGCTTGTGCGGGCCCCCGTCAATTCATTTGAGT & 831 \\
\hline AAD & 69 & $\begin{array}{l}\text { CTTATCGCGTTAC } \\
\text { IIIIIIIIIIII }\end{array}$ & 52 \\
\hline Sbjet & 30 & AGGCGGTCGACTTATCGCGTTAC & 71 \\
\hline AAD & & ГTTACGGCGTGGACTACCAGGG & \\
\hline Sbjet & 770 & АTCTCAAGGATCCCAACGGCTAGTCGACATCGTTTACGGCGTGGACTACCAGGGTATCTA & 111 \\
\hline AAD & 6 & 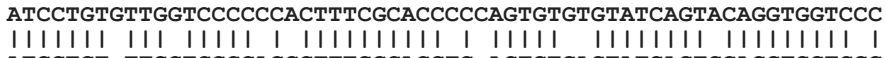 & \\
\hline Sbjet & 710 & АTCCTGT-TTGCTCCCCACGCTTTCGCACCTC-AGTGTCAGTATCAGTCCAGGTGGTCGC & 653 \\
\hline$A D$ & 49 & ССTTCTCCCACTGGTGTTTCCCTCСTATATCTACACATTTCACCCCCTACACAGGAGAAA & \\
\hline Sbjet & 652 & С-TTCGCC-ACTGGTG-TTCCTTCCTATATCTACGCATTTCACCGC-TACACAGGA-AAT & 598 \\
\hline AAD & & $\begin{array}{l}\text { CTACTGTAGTTTTGGATGCCGATTCCCCAGGGT } \\
|||||||||||||||||||||||||l| l \mid\end{array}$ & \\
\hline Sbjc & & CCACCACCC-T-CTACCGTACTCTAGCT-CAGTAGTTTTGGATGCAG-TTCCC-AGG-T & 544 \\
\hline AAD & & $\begin{array}{l}\text { AACATTGCTGCAGTCACCCAC } \\
|||||||||||||| \mid\end{array}$ & \\
\hline Sbj & 543 & CAA-C-TTGCTGAAC-CACCTACGC-G-CGCTTT-A & 493 \\
\hline AAD & & 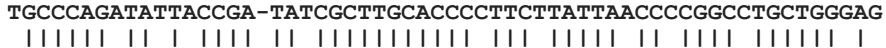 & 98 \\
\hline Sbjc & 4 & CGCCCAG-TAATTCCGATTAACGCTTGCACCC-TTCGTATTA-CCGCGGC-TGCTGGCA- & 438 \\
\hline AAD & & $\begin{array}{l}\text { CGAAAATTAGACCGGGGGTACTCCTGTCTGGTTGACCGTCCAAACAAGCACGGCGAGTG } \\
|||||||||||||||||||||||||||||||||||||||l| l \mid\end{array}$ & \\
\hline Sbj & 437 & CGAAG-TTAG-CCGGTGCTTATTC-TGT-TGGTA-AC-GTCAAAACA-GCAAGGT-ATT- & 387 \\
\hline $\mathrm{AAD}$ & 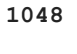 & $\begin{array}{l}\text { AAGATGAGTGTCCCTTCCCTCTCCAGACTTAATGTGCATTACAATCCGA-GAC } \\
||||||||||||||||||||||||||||||||||||||\end{array}$ & \\
\hline & & ААСTT-ACTG-СССТTCC-TC-CCA-АCTTAAAGTGCTTTACAATCCGAAGAC & \\
\hline
\end{tabular}

Fig. 2. Partial DNA sequences of the 16S rDNA gene of the bacterial strain AAD isolated from agricultural wastewater and the corresponding gene of Pseudomonas aeruginosa strain PAO1 (accession number: NR0748281). 


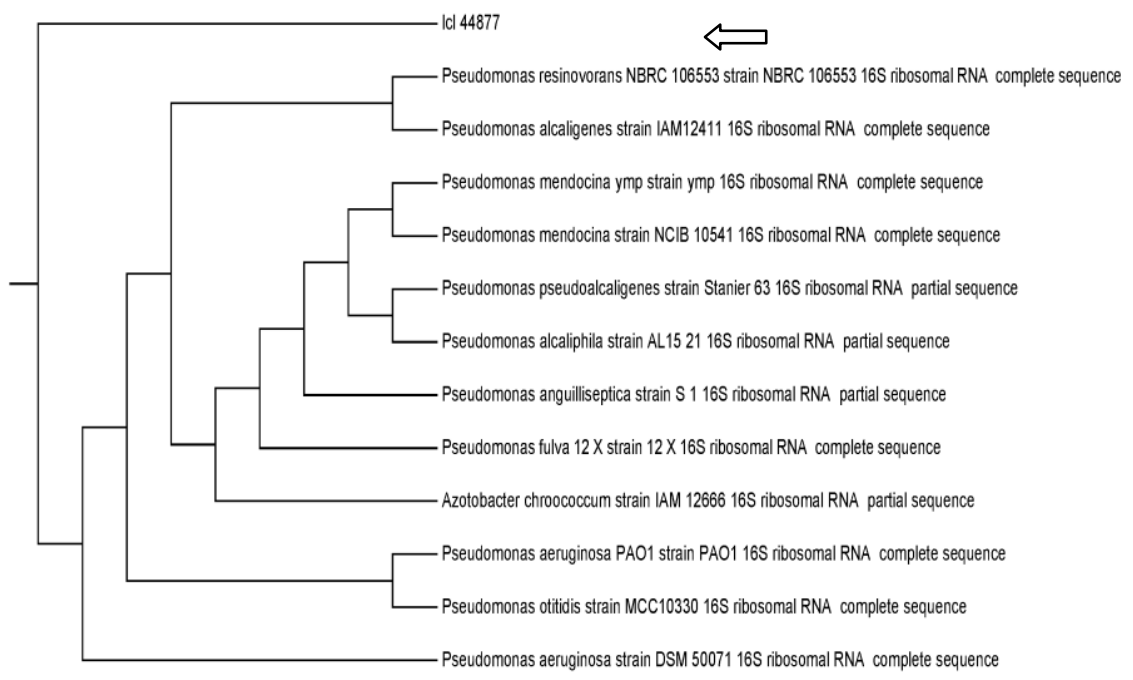

Fig. 3. Phylogenetic dendrogram obtained by distance matrix analysis of 16S rDNA sequences showing the position of the bacterial isolate AAD among phylogenetic neighbors. The black arrow indicates the position of AAD strain.

Growth optimization and diazinon degradation of P. aeruginosa

The obtained data highlighted the prominent capability of $P$. aeruginosa isolated from agricultural wastewater, to tolerate elevated levels of diazinon up to $500 \mathrm{ppm}$. Data in Fig. 4 showed that the growth of $P$. aeruginosa in the minimal media supplemented with diazinon as a sole carbon source was increased by increasing diazinon concentration up to $500 \mathrm{ppm}$ then the growth decreased at higher concentrations. Within 14 days incubation, the maximum cell density (1.15) was recorded with $500 \mathrm{ppm}$ while the maximum protein content $(217.6 \mathrm{mg} / \mathrm{L})$ was achieved with $400 \mathrm{ppm}$ of diazinon.

Moreover, the obtained results demonstrated the effect of temperature on the growth of P. aeruginosa (Fig. 5) and biodegradation rate of diazinon (Fig. 7 and Table 2). The maximum optical density (1.09) and protein content (349.4 mg/L) and diazinon degradation (83.6\%) was demonstrated at $30^{\circ} \mathrm{C}$ after 14 days of incubation. At higher temperature, a clear inhibition in the optical density, protein contents and percentage of diazinon degradation was recorded. At the same time, moderate bacterial growth and diazinon biodegradation rate was demonstrated at $20^{\circ} \mathrm{C}$.

Concurrently, the change in the $\mathrm{pH}$ value demonstrated a remarkable outcome on the growth of $P$. aeruginosa (Fig. 6). The maximum optical density (1.15) and protein content $(328.5 \mathrm{mg} / \mathrm{L})$ and diazinon degradation $(83.6 \%)$ was recorded at $\mathrm{pH} 7.0$ within 14 days. In the meantime, the recorded growth parameters and diazinon degradation were significantly reduced at the $\mathrm{pH}$ levels 5.0 and 9.0 (Fig. 7 and Table 2).

Egypt. J. Bot., Vol. 56, No. 1 (2016) 

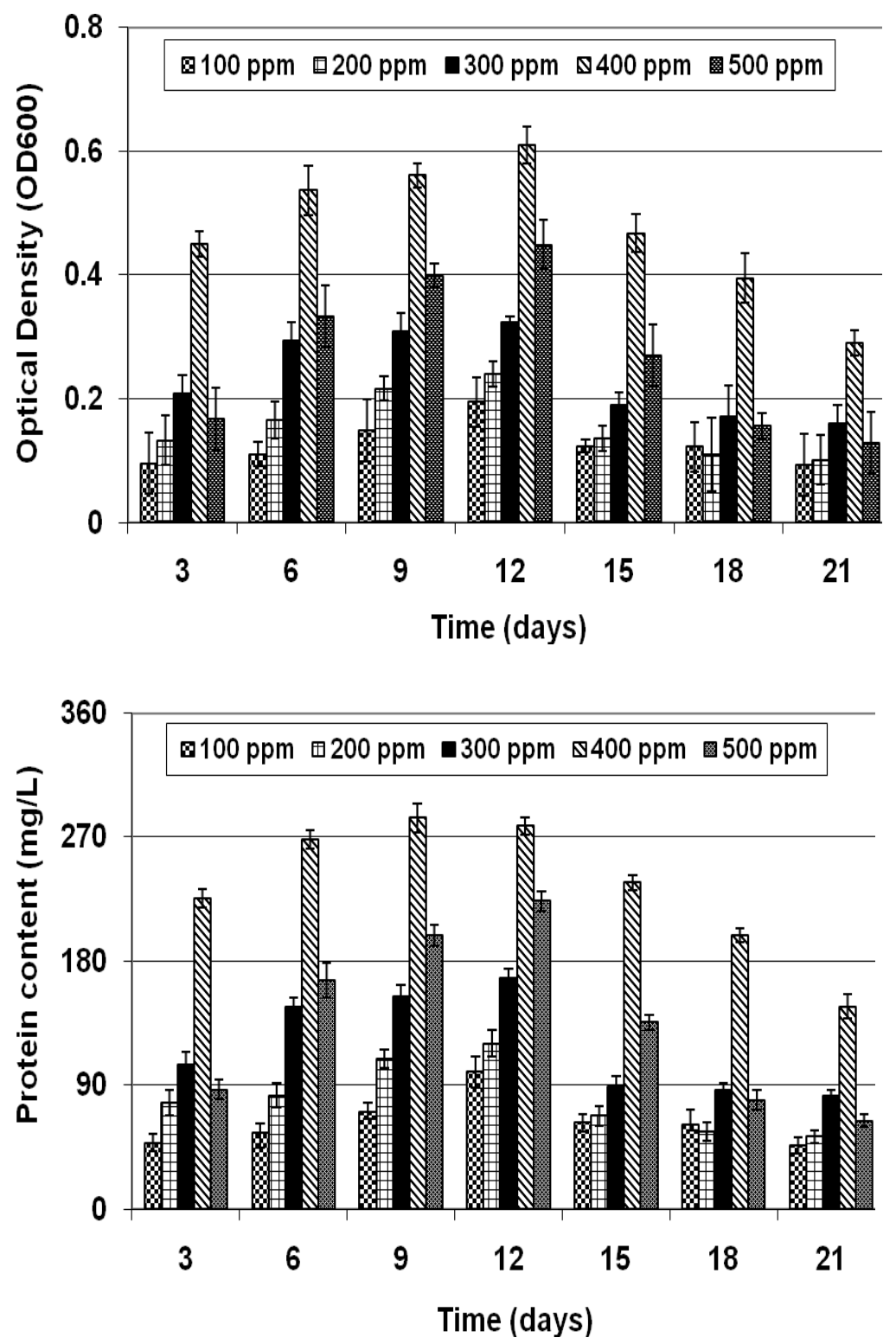

Fig. 4. Effect of diazinon concentration on the growth of Pseudomonas aeruginosa, (A) represents the optical density $\left(\mathrm{OD}_{600}\right)$ while $(B)$ represents the protein content $(\mathrm{mg} / \mathrm{L})$ of the bacterial growth. Data are the means of three replicates and error bars represent the standard errors of the means. 

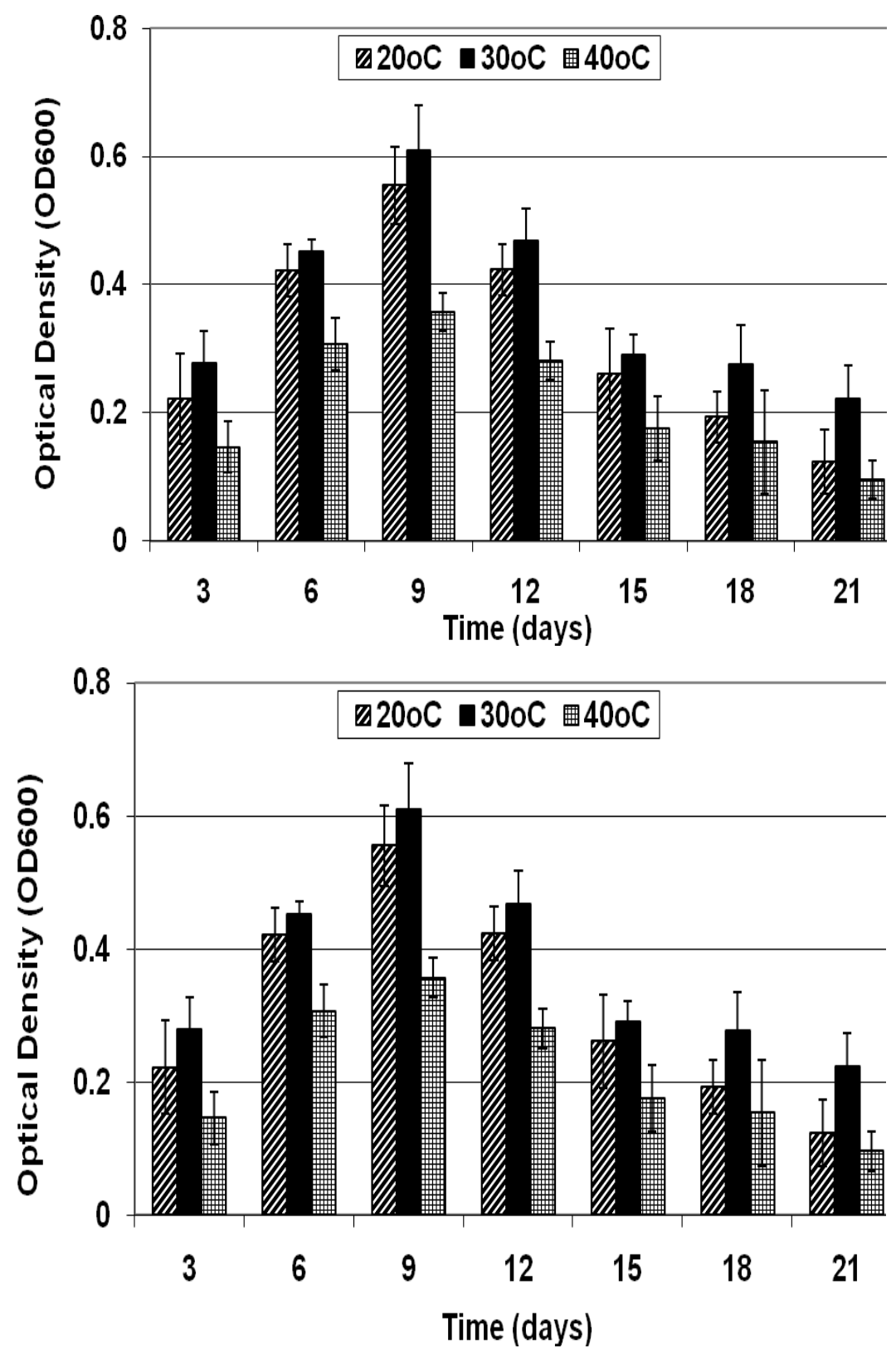

Fig. 5. Effect of temperature on the growth of Pseudomonas aeruginosa, (A) represents the optical density $\left(\mathrm{OD}_{600}\right)$ while $(B)$ represents the protein content $(\mathrm{mg} / \mathrm{L})$ of the bacterial growth. Data are the means of three replicates and error bars represent the standard errors of the means. 
BIODEGRADATION OF THE ORGANOPHOSPHORUS INSECTICIDE ... 363
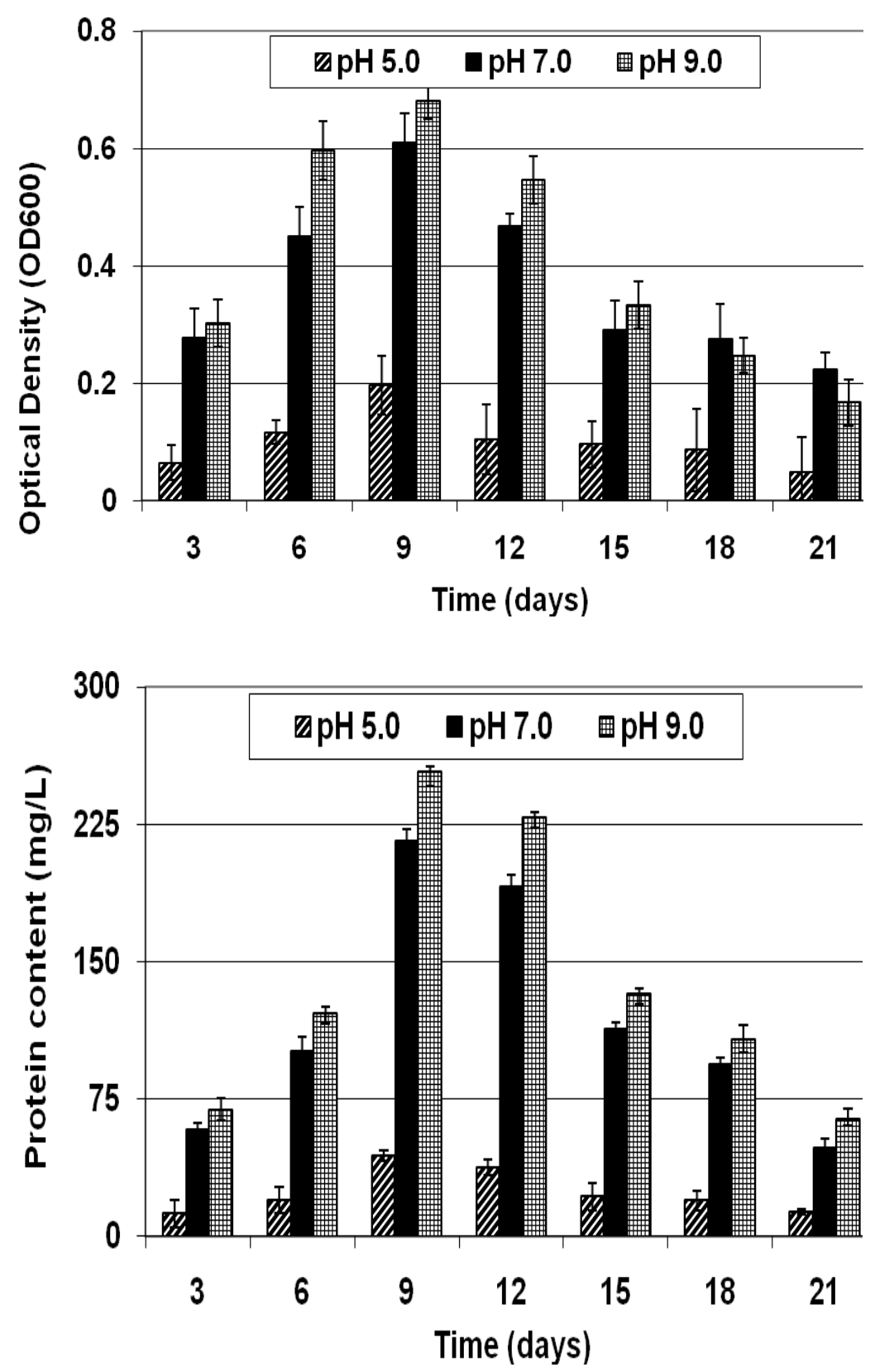

Fig. 6. Effect of pH value on the growth of Pseudomonas aeruginosa, (A) represents the optical density $\left(O D_{600}\right)$ while $(B)$ represents the protein content $(\mathrm{mg} / \mathrm{L})$ of the bacterial growth. Data are the means of three replicates and error bars represent the standard errors of the means. 

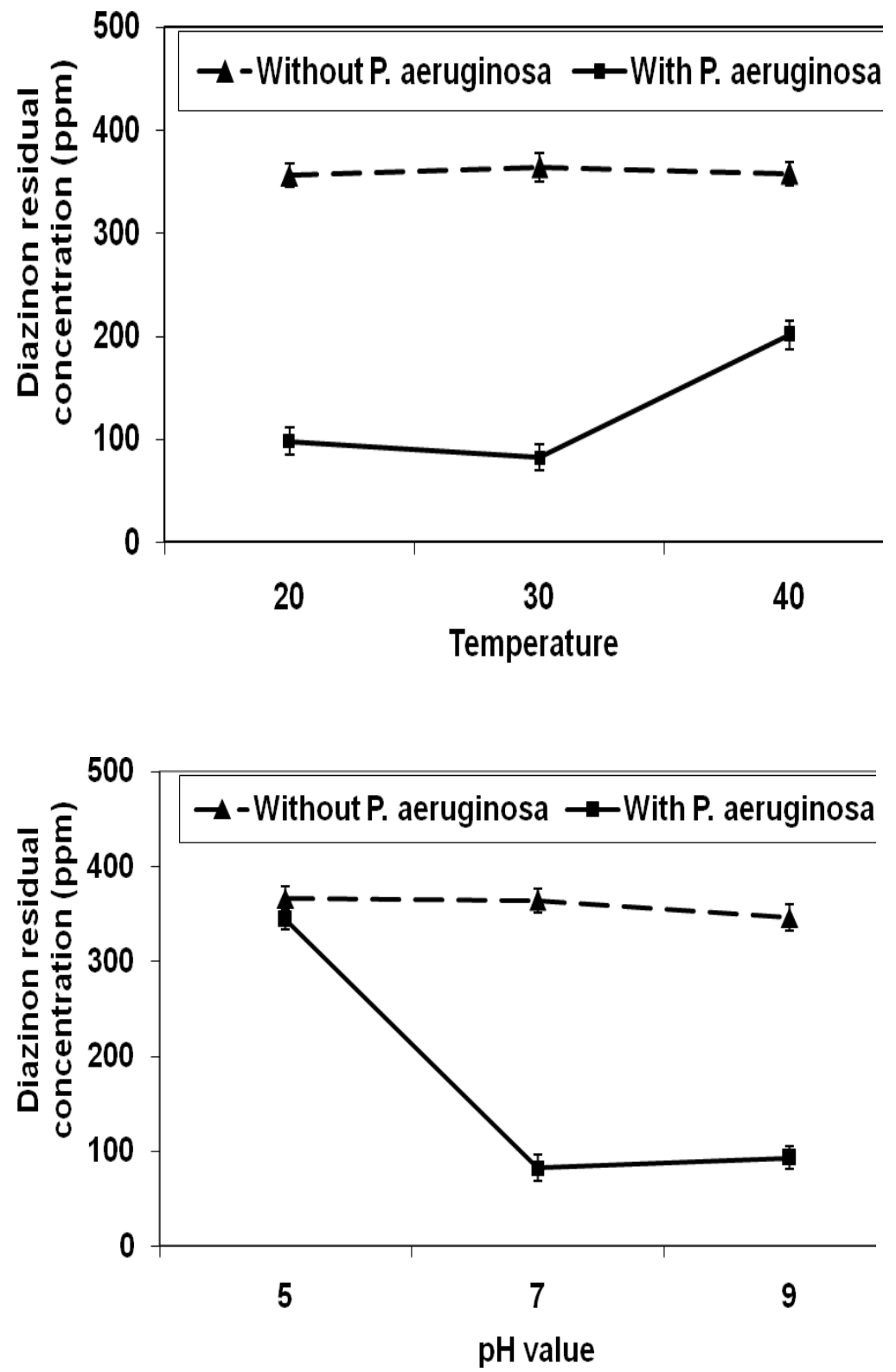

Fig. 7. Optimization of diazinon degradation by Pseudomonas aeruginosa where (A) represents the effect of $\mathrm{pH}$ value and $(\mathrm{B})$ represents the effect of temperature on the biodegradation process after 14 days. Initial concentration of diazinon was $368 \mathrm{ppm}$. Data are the means of three replicates and error bars represent the standard errors of the means.

Egypt. J. Bot., Vol. 56, No. 1 (2016) 
TABLE 2. The percentage of diazinon removal by Pseudomonas aeruginosa under different temperature and $\mathrm{pH}$ values after 14 days of incubation. The initial concentration was 368 ppm.

\begin{tabular}{|c|c|c|c|c|}
\hline \multirow{2}{*}{\multicolumn{2}{|c|}{ Treatment }} & \multirow{3}{*}{$\begin{array}{c}\begin{array}{c}\text { Retention } \\
\text { time } \\
(\mathbf{m i n})\end{array} \\
2.051 \\
\end{array}$} & \multicolumn{2}{|c|}{$\begin{array}{l}\text { Residual concentration of diazinon } \\
(\mathbf{p p m})\end{array}$} \\
\hline & & & with & without \\
\hline \multirow{3}{*}{$\mathrm{pH}$ value } & 5.0 & & $344 \pm 8$ & $366 \pm 12$ \\
\hline & 7.0 & 2.048 & $82 \pm 11$ & $364 \pm 10$ \\
\hline & 9.0 & 2.040 & $93 \pm 9$ & $346 \pm 8$ \\
\hline \multirow{3}{*}{ Temperature } & $20^{\circ} \mathrm{C}$ & 4.616 & $88 \pm 13$ & $356 \pm 12$ \\
\hline & $30^{\circ} \mathrm{C}$ & 4.609 & $82 \pm 10$ & $364 \pm 9$ \\
\hline & $37^{\circ} \mathrm{C}$ & 4.638 & $201 \pm 11$ & $358 \pm 8$ \\
\hline
\end{tabular}

\section{Discussion}

Isolation and identification of diazinon degrading bacteria

Microbial degradation is the primary route of the dissipation of the insecticide diazinon from the environment (Karpouzas and Singh, 2006). The bacterial isolate AAD that was isolated from agricultural drainage was highly tolerant to elevated concentrations of diazinon. Most agricultural fields are well drained, whereas hydrologic conditions in ditches can shift widely. Passage of agricultural runoff through vegetated drainage ditches has been shown to accumulate high levels of pesticides (Moore et al., 2008 and Moore et al., 2011). The microbial communities of the agricultural wastewater usually contain certain bacterial strains that can tolerate elevated concentrations of the toxic pesticides and might have the capability to mineralize these compounds (Tyler et al., 2013). Based on the morphological, biochemical assays in addition to 16S rDNA gene sequencing, AAD isolate was included in the genus Pseudomonas and closely related to the species aeruginosa.

Growth optimization and diazinon degradation of $P$. aeruginosa

The bacterial isolate $P$. aeruginosa demonstrated a marked potentiality to tolerate elevated levels of diazinon up to $500 \mathrm{ppm}$. It is well known that Pseudomonas is highly active bacteria and has the ability to utilize wide range of organic compounds. A number of studies recorded the isolation of Pseudomonas strains from different environments contaminated with diazinon and other organophosphorus pesticides (Sorensen et al., 2008; Ortiz-Hernandez et al., 2013).

This study showed that the growth of $P$. aeruginosa was increased by increasing diazinon concentration up to $500 \mathrm{ppm}$ then the bacterial growth was decreased at higher concentrations.. These findings are in harmony with those obtained with Abo-Amer and Aly (2011) who studied the effect of diazinon concentration on the growth of a diazinon degrading bacteria Serratia marcescens. This strain showed a high ability for the utilization of diazinon as 
carbon and phosphorus source. At low diazinon concentrations, complete degradation was achieved within 9 days while at higher concentrations only $40 \%$ was degraded within 16 days. Moreover, Mahiudddin et al. (2014) demonstrated similar results for the degradation of diazinon by the bacterial isolates Pseudomonas peli, Burkholderia caryophylli and Brevundimonas diminuta within 12 days of incubation. Also, Cycon et al. (2009) reported an elevated rate of diazinon degradation by Serratia sp. and Pseudomonas sp. within 14 days when it was added to MSM at low concentration.

The persistence of diazinon in the environment is strongly influenced with the existence and activity of microorganisms. As a result of the bacterial degradation of diazinon, some of the released products could be used as a carbon and phosphorus sources by the degrading bacteria (Thabit and El-Naggar, 2013). At the same time, the rate of the diazinon degradation is directly influenced with the physicochemical factors such as temperature, $\mathrm{pH}$, organic carbon and moisture content (Gunther, 1974). The present investigation showed that the maximum bacterial growth and diazinon degradation were achieved at $30^{\circ} \mathrm{C}$ after 14 days of incubation. Meanwhile a clear inhibition in the microbial growth and diazinon degradation rate were recorded at high temperature levels These results are in agreement with those reported by Abo-Amer (2012) who studied the effect of temperature on the degradation of the organophosporus pesticides by Pseudomonas $s p$ isolated from agricultural soils. It was found that the maximum rate of pesticide degradation was recorded at $20^{\circ} \mathrm{C}$ and $37^{\circ} \mathrm{C}$. At the same time, Abo-Amer and Aly (2011) showed that the optimal incubation temperature for diazinon degradation by Serratia marcescens was recorded between $25^{\circ} \mathrm{C}$ and $30^{\circ} \mathrm{C}$ while, a low degradation rate was demonstrated at extreme temperatures.

Similarly, the highest bacterial growth rate and diazinon degradation were recorded at $\mathrm{pH} 7.0$ within 14 days. These outcomes are in harmony with the studies of Abo-Amer and Aly (2011) who recorded remarkable changes in degradation rates of diazinon by Serratia marcescens at different $\mathrm{pH}$ values. Diazinon was completely degraded on within 11 days at $\mathrm{pH}$ values between 7.0 and 8.0 while, the degradation rate was sharply inhibited at $\mathrm{pH} 5.0$ and $\mathrm{pH} 10.0$. In the same way, Drufovka et al. (2008) found that $\mathrm{pH}$ value had a clear influence on microbial degradation of chlorpyrifos, fenitrothion and parathion.

\section{Conclusion}

A diazinon tolerant bacterial strain was isolated from agricultural drainage ditches by enrichment technique. This strain that was identified by $16 \mathrm{~S}$ rDNA techniques as Pseudomonas aeruginosa, showed a high capabilty to utilize diazinon as a sole carbon source. A remarkable rate of diazinon degradation was achieved at $\mathrm{pH}$ value 7.0 and temperature $30^{\circ} \mathrm{C}$ within 14 days. As a consequence, $P$. aeruginosa could be used effectively for the environmental cleanup of agricultural wastewater contaminated with high levels of diazinon and to minimize the levels of such these insecticides carried downstream ecosystems.

Egypt. J. Bot., Vol. 56, No. 1 (2016) 


\section{References}

Abo-Amer, A. (2012) Characterization of a strain of Pseudomonas putida isolated from agricultural soil that degrades cadusafos (an organophosphorus pesticide). World $J$. Microbiol. Biotechnol., 28, 805-814.

Abo-Amer, A. and Aly, E. (2011) Biodegradation of diazinon by Serratia marcescens di101 and its use in bioremediation of contaminated environment. J. Microbiol. Biotechnol., 21, 71-80.

Aislabie, J. and Lloyd-Jones, G. (1995) A review of bacterial degradation of pesticides. Aust. J. Soil Res., 33, 925-942.

Bakry, N.M., El-Rashidy, A.H., Eldefrawi, A.T. and Eldefrawi, M.E. (2006) Direct actions of organophosphate anticholinesterases on nicotinic and muscarinic acetylcholinic receptors. J. Biochem. Toxicol., 3, 235-259.

Bradford, M.M. (1976) A rapid and sensitive method for the quantition of microgram quantities of protein utilizing the principle of protein-dye binding. Anal. Biochem., 72, 248-254.

Courdouan, A., Marcacci, S. and Gupta, S., Schwitzguebel, J.P. (2004) Lindane and technical HCH residues in Indian soils and sediments: a critical appraisal. J. Soil Sediments, 4, 192-196.

Cycon, M., Wojcik, M. and Piotrowska-Seget, Z. (2009) Biodegradation of the organophosphorus insecticide diazinon by Serratia sp. and Pseudomonas sp. and their use in bioremediation of contaminated soil. Chemosphere, 76, 494-501.

Drufovka, K., Danevcic, T., Trebse, P., Stopar, D. (2008) Microorganisms trigger chemical degradation of diazinon. Int. Biodeter. Biodeg. 62, 293-296.

Essa, A.M.M. (2012) Effect of continuous mercury stress on mercury reducing community of some characterized bacterial strains. Afr. J. Microbiol. Res., 6, 12551261.

Getzin, L.W. (1967) Metabolism of diazinon and zinophos in soils. J. Econ. Entomol. 60, 505-8.

Ghassempour, A., Mohammadkhah, A., Najafi, F. and Rajabzadeh, M. (2002) Monitoring of the pesticide diazinon in soil, stem and surface water of rice fields. Anal. Sci., 18, 779-783.

Gunther, A.F. (1974) Residues of pesticides and other contaminants in the total environment, Residue Reviews, Springer-Verlag 51.

Hussaini, S.Z., Shaker, M. and Iqbal, M.A. (2013) Isolation of bacterial for degradation of selected pesticides. Adv. Biores., 4, 82-85. 
Ibrahim, W.M. and Essa, A.M.M. (2010) Tolerance, biodegradation and utilization of malathion, an organophosphorous pesticide, by some cyanobacterial isolates. Egypt. J. Botany, 27, 225- 240.

Kanekar, P.P., Bhadbhade, B.J., Deshpande, N.M. and Sarnaik, S.S. (2004) Biodegradation of organophosphorous pesticides. Proc. Nat. Sci. Acad. India, 70, 5770.

Karpouzas, D.G. and Singh, B.K. (2006) Microbial degradation of organophosphorus xenobiotics: Metabolic pathways and molecular basis. Adv. Microbiol. Physiol., 51, 119-185.

Lakshmi, C., Kumar, M. and Khanna, S. (2008) Biotransformation of chlorpyrifos and bioremediation of contaminated soil. Int. Biodeter. Biodeg., 62, 204-209.

Levin, L.A. and Forchiassin, V.A. (2003) Degradation of organic pollutants by the white rot Basidiomycete Trametes trogii. Int. Biodeter. Biodeg., 52, 1-5.

Liu, A.J. (2003) The isolation of atrazine degrading microbe and the research of degradation characteristics, $M S c$, Shandong agricultural university, Taiwan.

Mahiudddin, M., Fakhruddin, A.N.M., Abdullah, A., Chowdhury, M.A.Z., Rahman, M.A. and Alam, M.K. (2014). Degradation of the organophosphorus insecticide diazinon by soil bacterial isolate. Int. J. Biotechnol., 3, 12-23.

Massoud, A.H., El-Fakhrany, I.I., Abd El-Razik, M.A.S. (2007) Monitoring of some agrochemical pollutants in surface water in Kafr El-Sheikh Governorate. J. Pest. Cont. Environ. Sci., 15, 21-41.

Moore, M.T., Denton, D.L., Cooper, C.M., Wrysinski, J., Miller, J.L., Erner, I., Horner, G., Crane, D., Holcomb, D.B. and Huddleston, G.M. (2011) Use of vegetated agricultural drainage ditches to decrease pesticide transport from tomato and alfalfa fields in California, USA. Environ. Toxicol. Chem., 30, 1044-1049.

Moore, M.T., Denton, D.L., Cooper, C.M., Wrysinski, J., Miller, J.L., Reece, K., Crane, D. and Robins, P. (2008) Mitigation assessment of vegetated drainage ditches for collecting irrigation runoff in California. J. Environ. Qual., 37, 486-493.

Mulchandani, A., Kaneva, I., Chen, W. (1999) Detoxification of organophosphate pesticides by immobilized Escherichia coli expressing organophosphorus hydrolase on cell surface. Biotechnol. Bioeng., 63, 216-223.

Ohshiro, K., Kakuta, T., Sakai, T, Hirota, H., Hoshino, T. and Uchiyama, T. (1996) Biodegradation of organophosphorus insecticides by bacteria isolated from turf green soil. J. Ferment. Bioeng., 82, 299-305.

Ortiz-Hernandez, M.L. and Sanchez-Salinas, E. (2010) Biodegradation of the organophosphate pesticide tetrachlorvinphos by bacteria isolated from agricultural soils in Mexico. Rev. Int. Contam. Ambient, 26, 27-38.

Ortiz-Hernandez, M.L., Sanchez-Salinas, E., Castrejon Godinez M.L., Dantan Gonzalez E. and Popoca Ursino, E.C. (2013) Mechanisms and strategies for 
pesticide biodegradation: opportunity for waste, soils and water cleaning. Rev. Int. Contam. Ambient, 29, 85-104.

Ramanathan, M.P. and Lalithakumari, D. (1999) Complete mineralization of methylparathion by Pseudomonas sp. A3. Appl. Biochem. Biotechnol., 80, 1-12.

Reyad, A.M.M., Radwan, T.E.E., Ibrahim, W.M. and Essa, A.M.M. (2014) Atrazine degradation in liquid culture by Ochrobactrum oryzae isolated from the agricultural wastewater. Wulfenia J., 21, 286-310.

Richins, D., Kaneva, I., Mulchandanim A. and Chen, W. (1997) Biodegradation of organophosphorus pesticides by surface expressed organophosphorus hydrolase. Nat. Biotechnol., 15, 984-987.

Schoefs, O., Perrier, M. and Samson, R. (2004) Estimation of contaminant depletion in unsaturated soils using a reduced-order biodegradation model and carbon dioxide measurement. Appl. Microbiol. Biotechnol., 64, 256-61.

Selim, H.M.M., Gomaa, N.M. and Essa, A.M.M. (2014). Comparative in-vitro study of the antimicrobial activities of the endophytic bacteria Stenotrophomonas, Bacillus and Pseudomonas. Wulfenia J., 21(4), 1-26.

Sethunathan, N.N. and Yoshida, T. (1973) A Flavobacterium that degrades diazinon and parathion. Can. J. Microbiol., 19, 873-875.

Sorensen, S.R., Albers, C.N. and Aamand, J. (2008) Rapid mineralization of the phenylurea herbicide diuron by Variovorax sp. strain SRS16 in pure culture and within a two member consortium. Appl. Environ. Microbiol., 74, 2332-2340.

Surekha, R.M., Lakshmi, P.K.L., Suvarnalatha, D., Jaya, M., Aruna, S., Jyothi, K., Narasimha, G. and Venkateswarlu, K. (2008) Isolation and characterization of a chlorpyrifos degrading bacterium from agricultural soil and its growth response. Afr. J. Microbiol. Res., 2, 26-31.

Thabit, T.M.A. and El-Naggar, M.A.H. (2013) Malathion degradation by soil isolated bacteria and detection of degradation products by GC-MS. Int. J. Environ. Sci., 3, $1467-1476$.

Tomlin, C.D.S. (2006) "The Pesticide Manual, A World Compendium". 14 $4^{\text {th }}$ ed. British Crop Protection Council (BCPC), Alton, Hampshire, UK.

Tyler, H.L., Khalid, S., Jackson, C.R. and Moore, M.T. (2013) Determining potential for microbial atrazine degradation in agricultural drainage ditches. J. Environ. Qual., 42, 828-834.

Yasouri, F.N. (2006) Plasmid mediated degradation of diazinon by three bacterial strains, Pseudomonas sp., Flavobacterium sp. and Agrobacterium sp. Asian. J. Chem.,18, 2437-2444. 
Zhang, J. and Quiao, C. (2002) Novel approaches for remediation of pesticide pollutants. Int. J. Environ. Poll., 18, 423-433.

( Received 27/7/2015; accepted 10/12/2015)

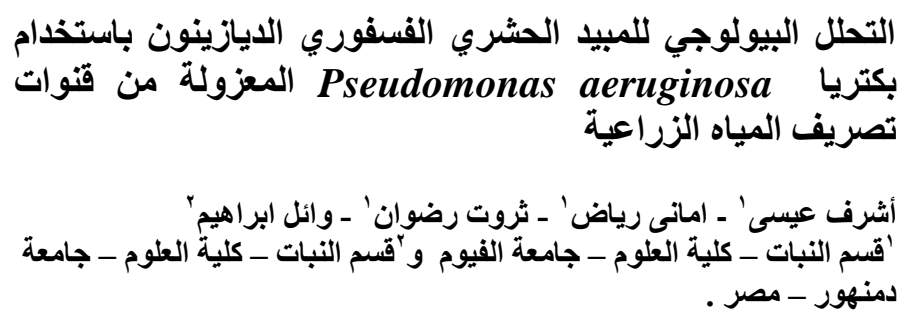

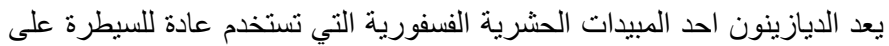

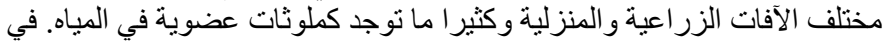

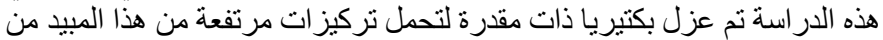

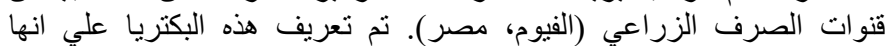
Pseudomonas aeruginosa

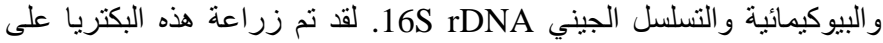

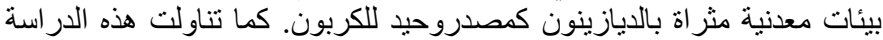

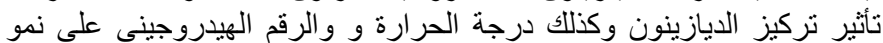

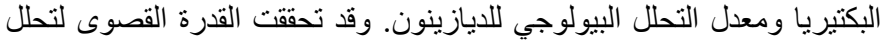

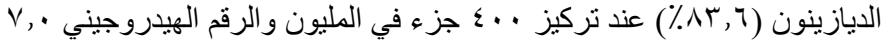

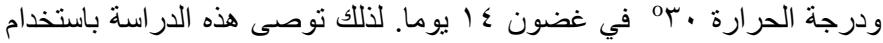

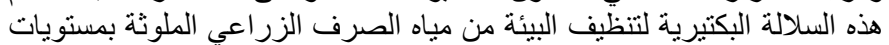
عالية من المبيد الحشري الديازينون. 